\title{
Simulation of the Effect of Land Cover Change on Water Balance and Sediment Yield of Wadi El Raml in the North Western Coast, Egypt
}

\author{
Ashraf N. El-Sadek and Ahmed H. Mohamed ${ }^{1}$
}

\begin{abstract}
Rainfed farming in the North Western Coast of Egypt represents the major source of food for the majority of the local Bedouins. Population growth associated with limited resources pushed the local Bedouins to alter their lands to move from rangelands to rainfed agriculture. In this study, i.e., wadi El Raml the Sentinel $2 \mathrm{~A}$ image launched in 2014 was used to define the main land cover types dominating the study area. The classified image showed six land cover classes i.e. water bodies (1.15\%), urban land $(11.43 \%)$, orchard trees $(10.42 \%)$, rainfed crops $(15.80 \%)$, sparsely vegetated land $(34.81 \%)$ and bare soil $(\mathbf{2 6 . 0 3 \%})$. The downstream impact of changing land cover in the upstream of Wadi El Raml was simulated using the semi distributed KINEROS2 model. Three assumed scenarios were tested; 1) converting the rangeland to rainfed agriculture of winter crops, 2) converting the bare soil to range land and 3 ) the base simulation which is the current situation. The primary results revealed that, overall the tested rain events changing the land cover type from rangelands to rainfed agriculture increased the basin average surface runoff and sediment yield by $6.39-15.37 \%$ and $16.29-36.45 \%$, respectively. It is recommended that a limited area should be converted from rangelands to rainfed agriculture.
\end{abstract}

Key words: Hydrological Modeling, Rangeland, Land use changes, Remote sensing

\section{INTRODUCTION}

A significant proportion of the arid and semi-arid regions is dominated by a sparsely vegetated land cover (Schmidt and Karnieli, 2000) . This is due to highly variable, short season rainfall followed by a long dry period causing a considerable reduction in land cover (Sen, 2008) . In the last few decades, the vegetation cover in the North Western Coastal Zone of Egypt was highly degraded as a result of long drought periods, wind erosion and unsustainable land use practices including firewood gathering, over-exploitation of rangelands and traditional tillage to grow rainfed cereals (mainly barley and wheat). The area has 218 wadis running from south to north (Wadi is the Arabic word for ephemeral water courses in arid regions), where main stream of the wadi and its delta are mainly occupied by olive and fig trees, while, the upstream is left for rainfed crops and natural vegetation. No studies

\footnotetext{
${ }^{1}$ Ecology and Dryland Agriculture Division, Desert Research Center,1 Mathaf El Mataria St., Cairo, Egypt

${ }^{1}$ Corresponding author e-mail: anelsadek@gmail.com

Received November 06,2017, Accepted December 30, 2017
}

in the area have explored the influences of the land cover change on the runoff behavior in the watersheds.

The impact of land cover changes either temporally or spatially on the watershed hydrological system was studied by many researchers (Li et al., 2016 and Fang et al., 2012). Mahmoud and Alazba (2015) studied the effect of land cover change in 2000 as compared to 1990 and its effect on the surface runoff of El Baha Region in Saudi Arabia. Results revealed that the surface runoff was declined in the majority of the area as a result for the transition from forest and shrubland to irrigated cropland. Also, the construction of different water harvesting projects decreased the amount of surface runoff component. However, the increase in the surface runoff occurred in a limited area. Masih et al., (2011) examined three scenarios of land cover change i.e., converting rainfed areas to irrigated agriculture, improving soil water availability by rain water harvesting structures and a combination between the two scenarios. The Soil and Water Assessment Model (SWAT) was used to evaluate the tested scenario on the flow of Karkheh basin in Iran. The results revealed a $10 \%$ reduction in the basin mean annual flow in the first scenario, however applying the second scenario caused a small reduction in the annual flow ranging from 2-5\%.

Watershed hydrology models are important in addressing the impact of many problems including land cover change related to water resources assessment and development (Dwarakish and Ganasri, 2015). Recently many physically distributed models were employed to detect the spatial and temporal land cover changes on water resources e.g., MIKE SHE (Refsgaard and Storm, 1995 and Im et al., 2009), SWAT (Arnold, 1998 and Pervez and Henebry, 2015), TOPMODEL (Beven and Kirkby, 1979 and Gumindoga et al., 2014). Miller et al., (2002) applied two hydrological models SWAT as a continuous simulation model and KINEROS (Smith et al., 1995) as an event oriented model, through the Automated Geospatial Watershed Assessment Tool (AGWA) to study the hydrologic responses of three watersheds to the land cover changes in four time periods 1973,1986,1992 and 1997 for the San Pedro River basin, and in 1975,1985,1991 and 1998 for the Cannonsville watershed, USA. The simulation results showed that both models were able to characterize the 
runoff response of the watershed due to changes of land cover.

The KINEROS hydrological model was chosen for this study for many reasons; 1 ) it is an event orientedphysically based model and suits the study of single hydrological event, 2) it was developed to study the hydrological processes in arid and semi-arid areas and 3 ) it is a GIS-based model that has capabilities of geovisualization for better understanding and comparing different model scenarios. The objectives of this study are 1) to investigate the impact of converting the rangeland to rainfed crops and the bare soil to rangelands on the hydrological behavior of Wadi ElRaml and 2) to evaluate the potentiality of a physically distributed model i.e., KINEROS in assessing the hydrology of data-scarce arid watershed.

\section{MATERIALS AND METHODS}

\section{Description of the Study area}

Wadi El-Raml basin occupies an area of about $144.35 \mathrm{~km}^{2}$ as delineated by the KINEROS model and is located at west of Marsa Matrouh City. It is located between $27^{\circ} 04^{\prime} 27^{\prime \prime}-27^{\circ} 12^{\prime} 30^{\prime \prime} \mathrm{E}$ and latitudes $31^{\circ} 09^{\prime}$ $20^{\prime \prime}-31^{\circ} 21^{\prime} 58^{\prime \prime} \mathrm{N}$ (Fig. 1). The study area is characterized by a temperate Mediterranean climate with an annual average $\mathrm{T}_{\max }$ and $\mathrm{T}_{\min }$ of 30 and $9^{\circ} \mathrm{C}$ ,respectively. The recorded maximum relative humidity varies from $73 \%$ to $63 \%$ (in July and March, respectively). The study area is characterized by short rainy season (Nov.-Feb.). December is the rainiest month with a monthly average of $32 \mathrm{~mm}$. The maximum annual rainfall was recorded in 1989/1990season $(275 \mathrm{~mm})$ while the annual mean value reaches $140 \mathrm{~mm}$.

$28^{\circ} 0^{\prime} 0 " \mathrm{E}$

$34^{\circ} 30^{\prime} 0^{\prime \prime E}$

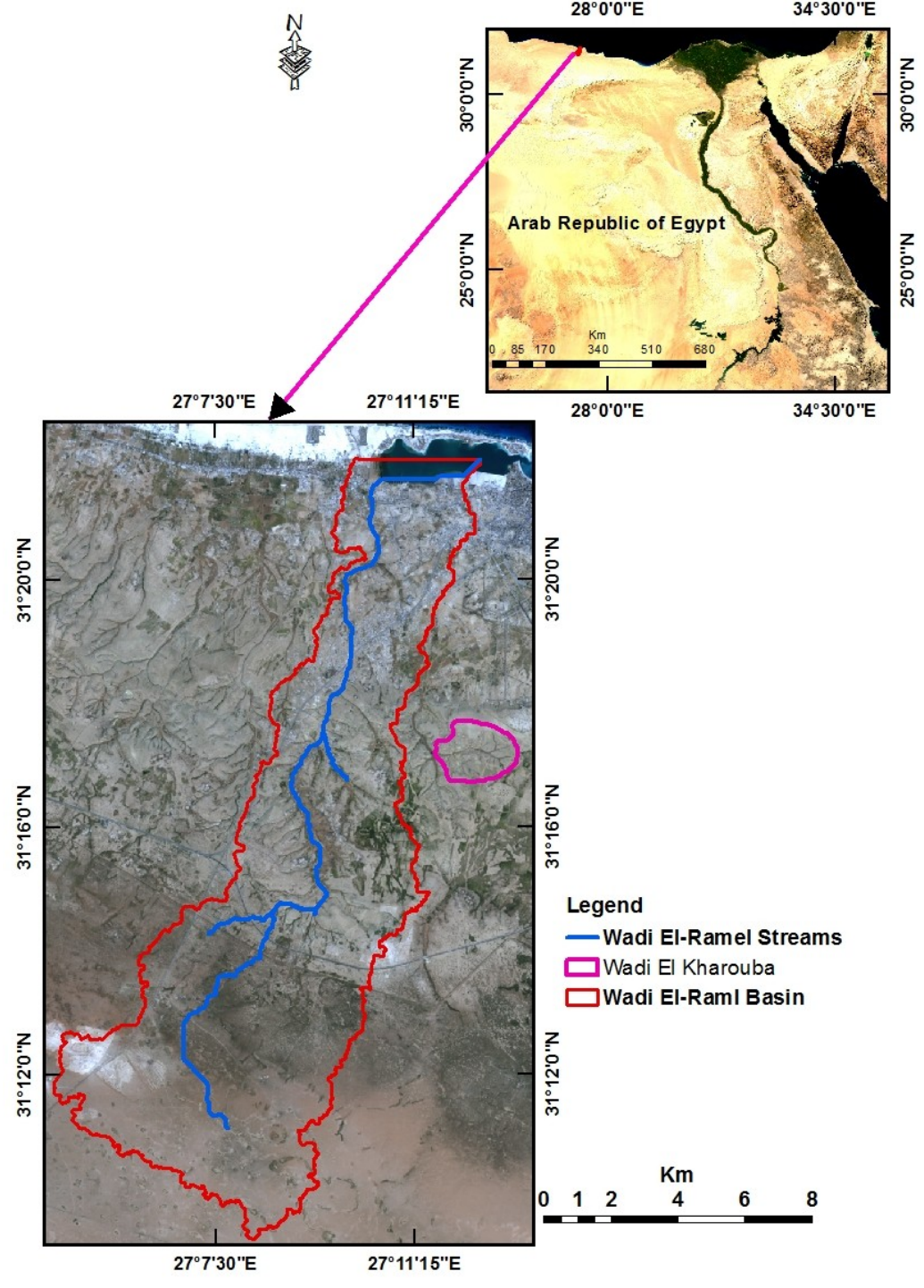

Figure 1.Location map showing the study area at the NW coastal zone of Egypt 


\subsection{Geomorphology and geology of the study area}

The geomorphic units of the north western coast of Egypt, including the study area, were documented by (Raslan, 1995, Masoud, 2000, Barseem et al., 2014). There are four landforms in the area i.e., coastal plain, piedmont plain, structural plateau, and finally hydrographic basins as shown in Figure 2. Furthermore, Raslan (1995) studied the stratigraphic sequences of the

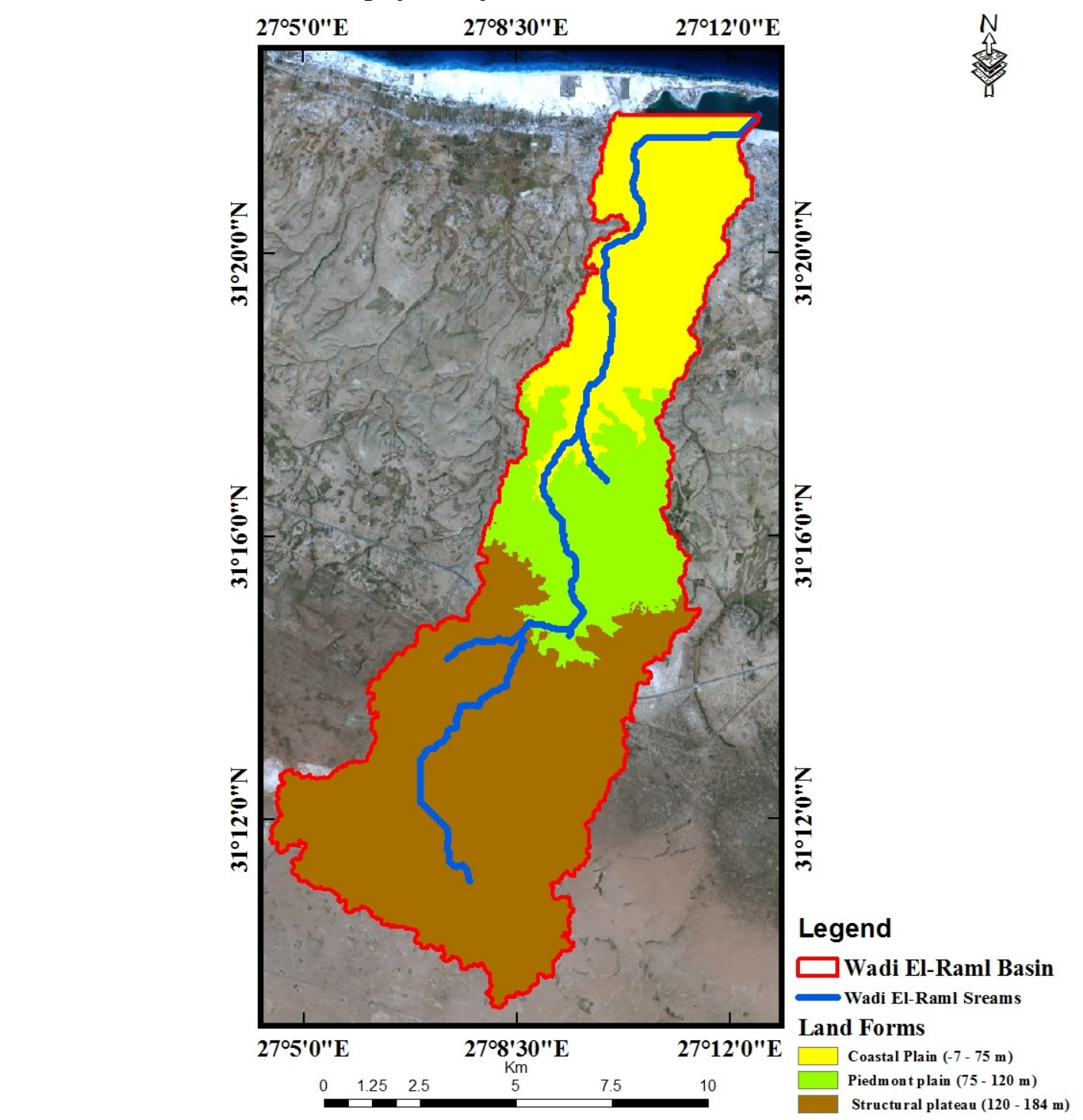

Figure 2. Geomorphologic map of the study area (modified after Raslan, 1995) entire study area and he concluded that it is composed of sedimentary origin ranging in age from the Middle Miocene to Quaternary (Fig. 3). The Middle Miocene sediments cover the structural plateau while the Quaternary sediments covers the surface of coastal plain, piedmont plain, and the hydrographic basins (Wadi course and its tributaries). 


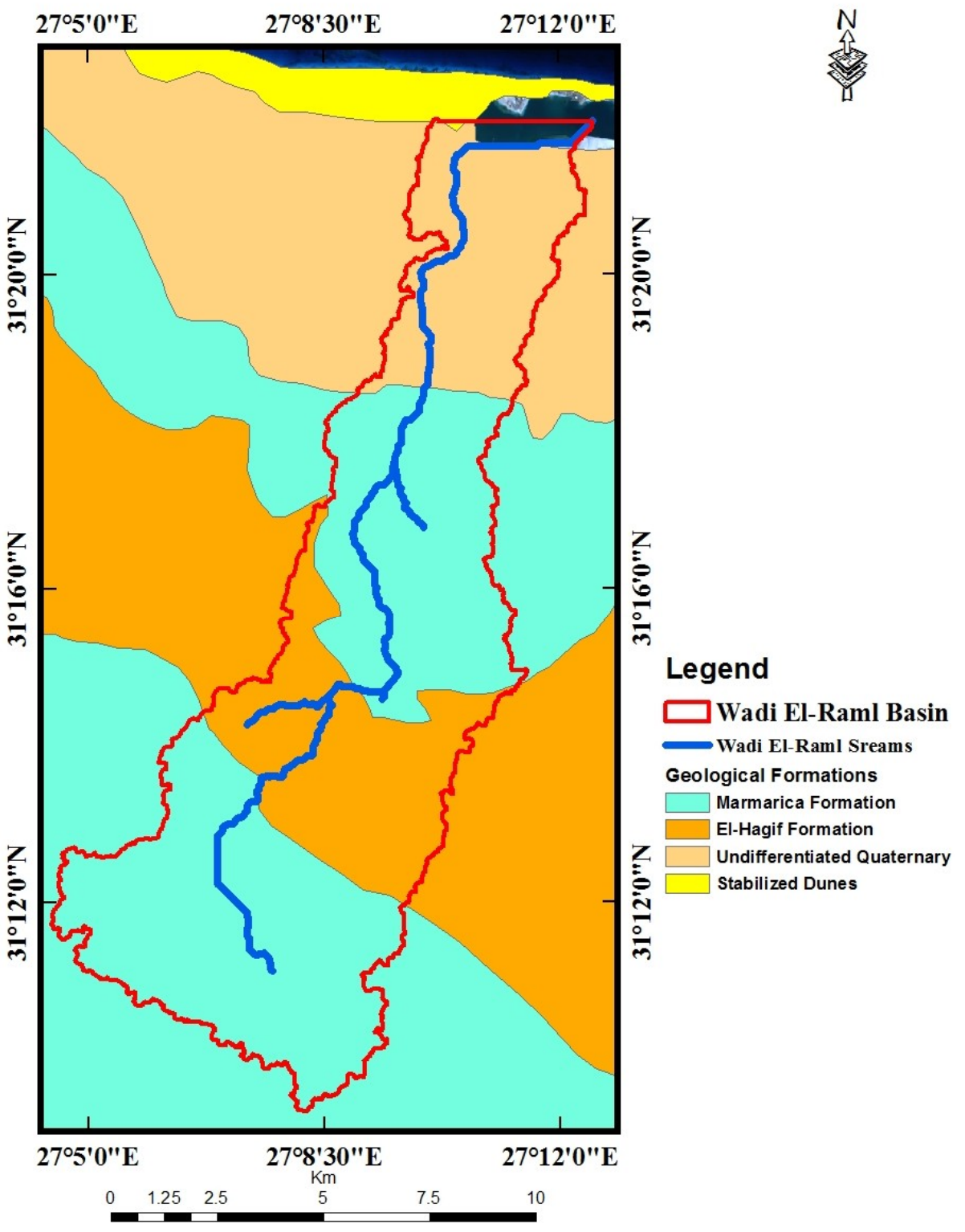

Figure 3. Geologic map of the study area

\subsection{Soil characteristics}

According to Khalifa and Beshay (2015) following the Soil Survey Staff (2014) the soil of the study area is classified as Lithic Torripsamments and Lithic Torriorthents in the structured plateau (planes of the Wadi). However, the wadi course, piedmont plain and coastal plain are characterized by Typic Torripsamments and Typic Torrifluvents soil groups.

\section{Evaluating the natural vegetation cover and cultivated area}

\section{1- Rangeland vegetation ground survey}

Rangeland vegetation ground survey was conducted in spring of 2015 to evaluate the rangeland status on the study area. Ten quadrates $(5 \mathrm{~m} \times 5 \mathrm{~m})$ were placed on each side of the Wadi El-Raml from South to North to study the rangeland vegetation on the area. Plant species were fully identified and named according to Tackholm (1974) updated by Boulos (1995). Vegetation measurements including plant density $\left(\mathrm{plant} / \mathrm{m}^{2}\right)$, plant frequency $(\%)$, and plant coverage $(\%)$ were calculated according to the methods described by MuellerDombois and Ellenberg (1974). The importance value for the plant species were estimated by calculating the sum of relative density, relative cover and relative frequency for the species, by dividing the cover, density, and frequency for each plant species by the total cover, density, and frequency for all species (Ludwig and Reynolds, 1988). 


\section{2- A field experiment for crop production}

Barley is the major winter crop grown in the watershed. It is mainly grown to feed livestock on grain, straw, and stubble. A small area is allocated for wheat production. The most common varieties are Giza 126 for barley and Sakha 93 for wheat. The crop production in the area is mainly based on rainfall with no supplemental irrigation, no mineral fertilization, and lack of crop rotation practice. The watershed received a total precipitation of $239 \mathrm{~mm}$ during the growing season of $2015 / 2016$ which is more than the recorded average of $140 \mathrm{~mm}$.

A limited field experiment was conducted to evaluate the productivity of wheat and barley in the watershed. Both crops were sown in 17 November 2015 and were harvested in 15 April 2016. No fertilizer applications were applied as practiced by the local farmers. Plants from 1 square meter were harvested to record some parameters i.e., plant height $(\mathrm{cm})$, number of grains/spike, 1000-grain weight $(\mathrm{g})$ grain yield $\left(\mathrm{g} / \mathrm{m}^{2}\right)$, straw yield $\left(\mathrm{g} / \mathrm{m}^{2}\right)$, biological yield $\left(\mathrm{g} / \mathrm{m}^{2}\right)$, harvest index (\%) and crop index $(\%)$.

\section{Geo-spatial data}

AGWA interface was used to derive all the necessary inputs for the KINEROS model. A $30 \mathrm{~m}$ digital elevation model (DEM) from SRTM (The Shuttle Radar Topography Mission) was obtained for the study area from the website of USGS (http://earthexplorer.usgs.gov $\mathrm{h}$ ), and the DEM layer is presented in Figure 4 . The model uses the DEM to generate information related to the topographic characteristics of the watershed: elevation, watershed boundary, flow path, sub-basin area, slope, and channels elevation. All soil data were obtained from the FAO/UNESCO (2003) Soil Map of the World CDROM at 1:3000,000 scale.

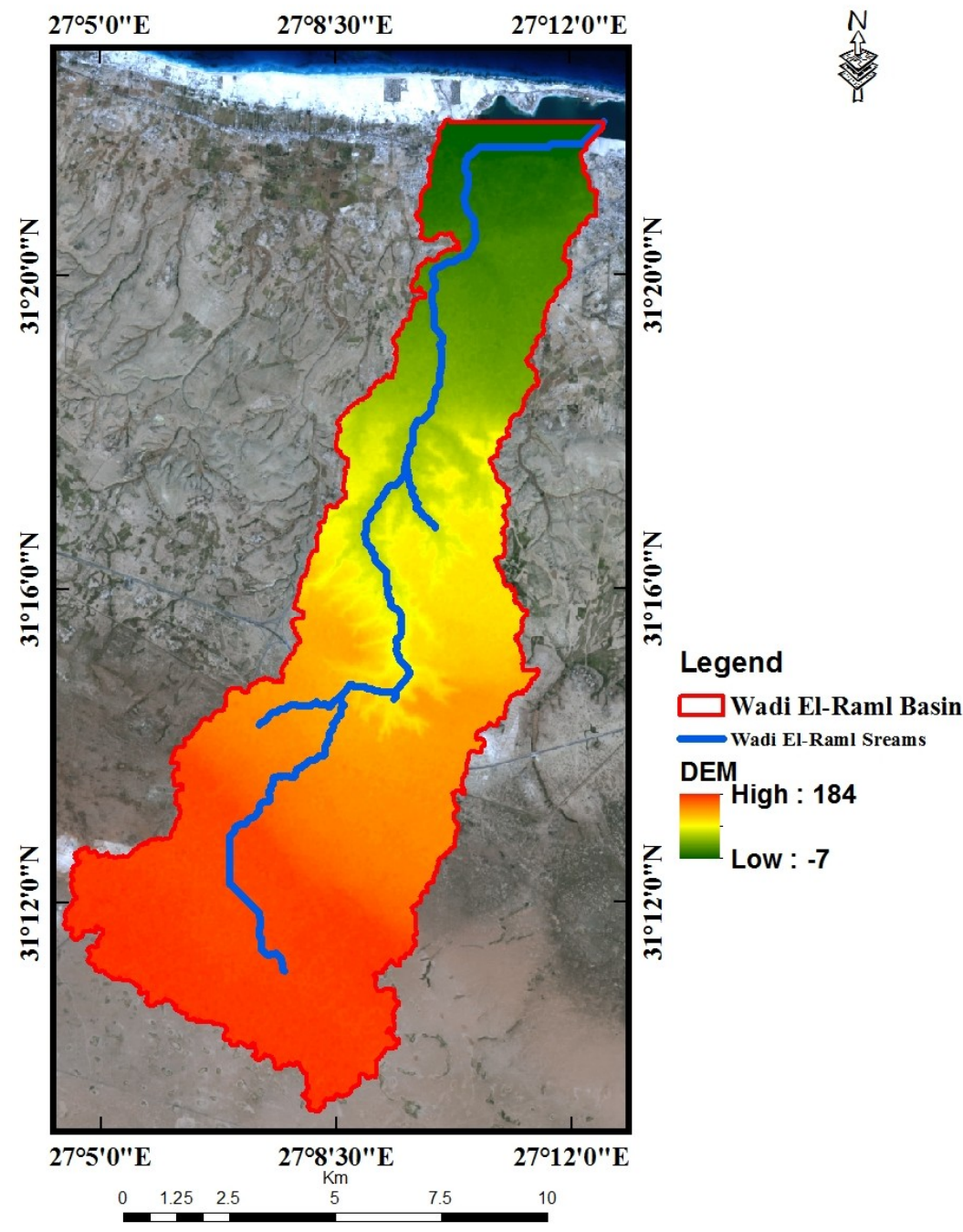

Figure 4. Digital Elevation Model of (DEM) the study area 


\subsection{Satellite image and Land Cover classifications}

A SENTINEL 2A satellite image acquired from the European Space Agency (https://scihub.copernicus.euli in spring, 2016 of the study area was used to produce land cover map for the study area. The SENTINEL-2A satellite images contain 13 bands at different spatial resolutions (between $10 \mathrm{~m}$ and $60 \mathrm{~m}$ ). For this study the Green, Blue, Red, and NIR bands with $10 \mathrm{~m}$ spatial resolution were merged and used to produce the land cover map. The primary targeted land cover classes in the study area were urban, bare soils, irrigated agricultural and sparse vegetation rangelands. Both pixel based classification techniques of unsupervised and supervised image classification were implemented. An ISODATA (Iterative Self-Organizing Data Analysis Technique) clustering, principal axis means computing, 25 maximum iterations, and a 95 percent convergence threshold unsupervised classification of the SENTINEL 2A satellite image was performed in ArcGIS Desktop 10. Accordingly, a number of 10 clusters were specified to classify the study area and visualize the spectral class composition of the image and estimate the number of classes which can be identified (Fig. 5).

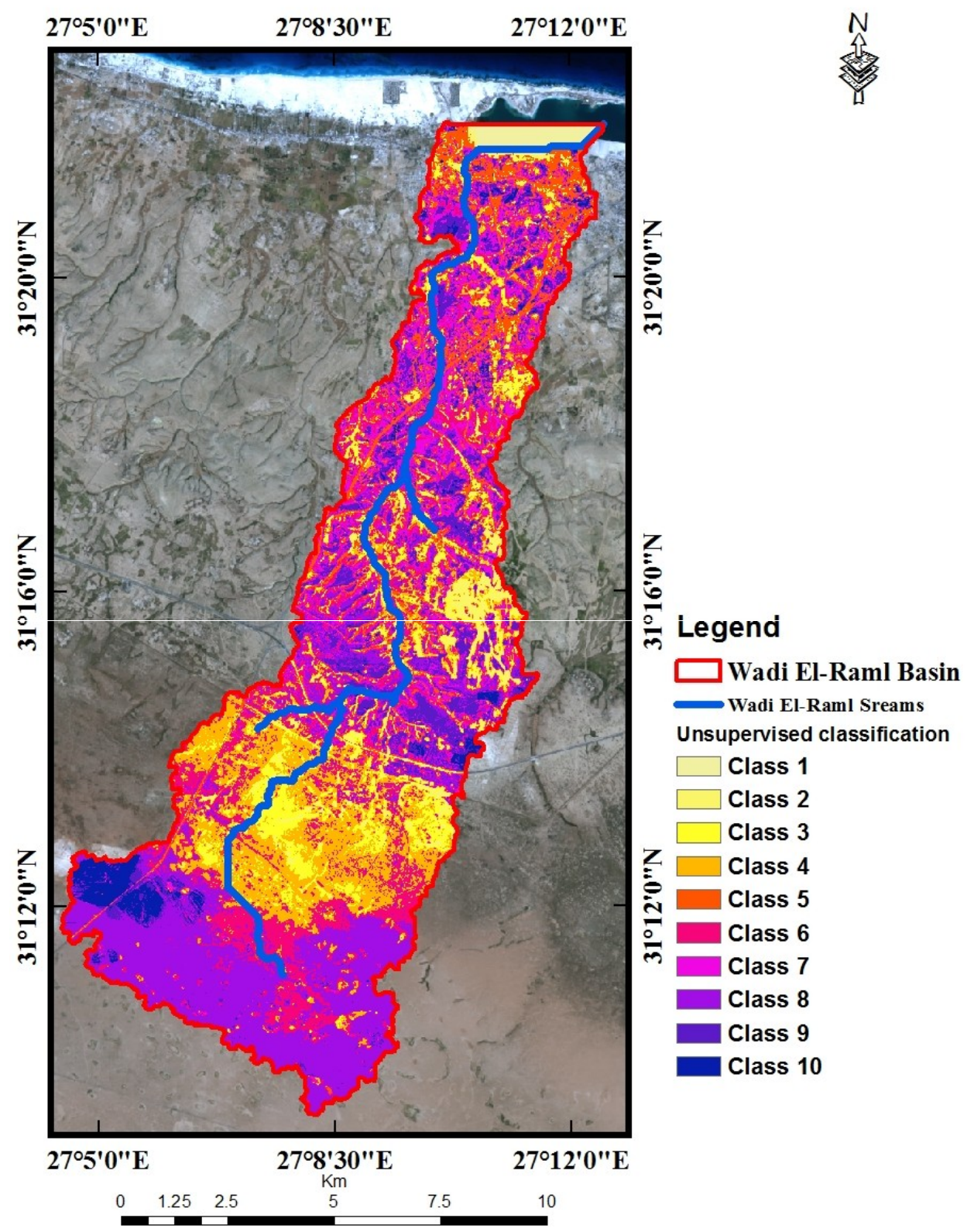

Figure 5. Unsupervised classification of the SENTINEL 2A satellite image 
A signature file for the different surface covers based on the data obtained from the field study was created. Finally, Maximum Likelihood Supervised Classification was conducted using ArcGIS desktop10. Land cover map with 6 classes of Wadi El-Raml was produced from satellite image supervised classification. These land cover types include water body, urban land, orchards trees, rain-fed crops, sparsely vegetated rangeland, and bare ground soils.

\section{Model description}

KINEROS2; is an event-oriented, distributed, physically-based model developed to simulate the runoff response in basins having predominantly overland flow (Semmens et al., 2008). The model has been modified for many years with the first version, named KINEROS, included the processes of erosion and sediment transport and was released by Woolhiser et al., (1990) and was described in details by Smith et al., (1995). The form of the model that we used in this study is part of the AGWA interface (Miller et al.,2007).
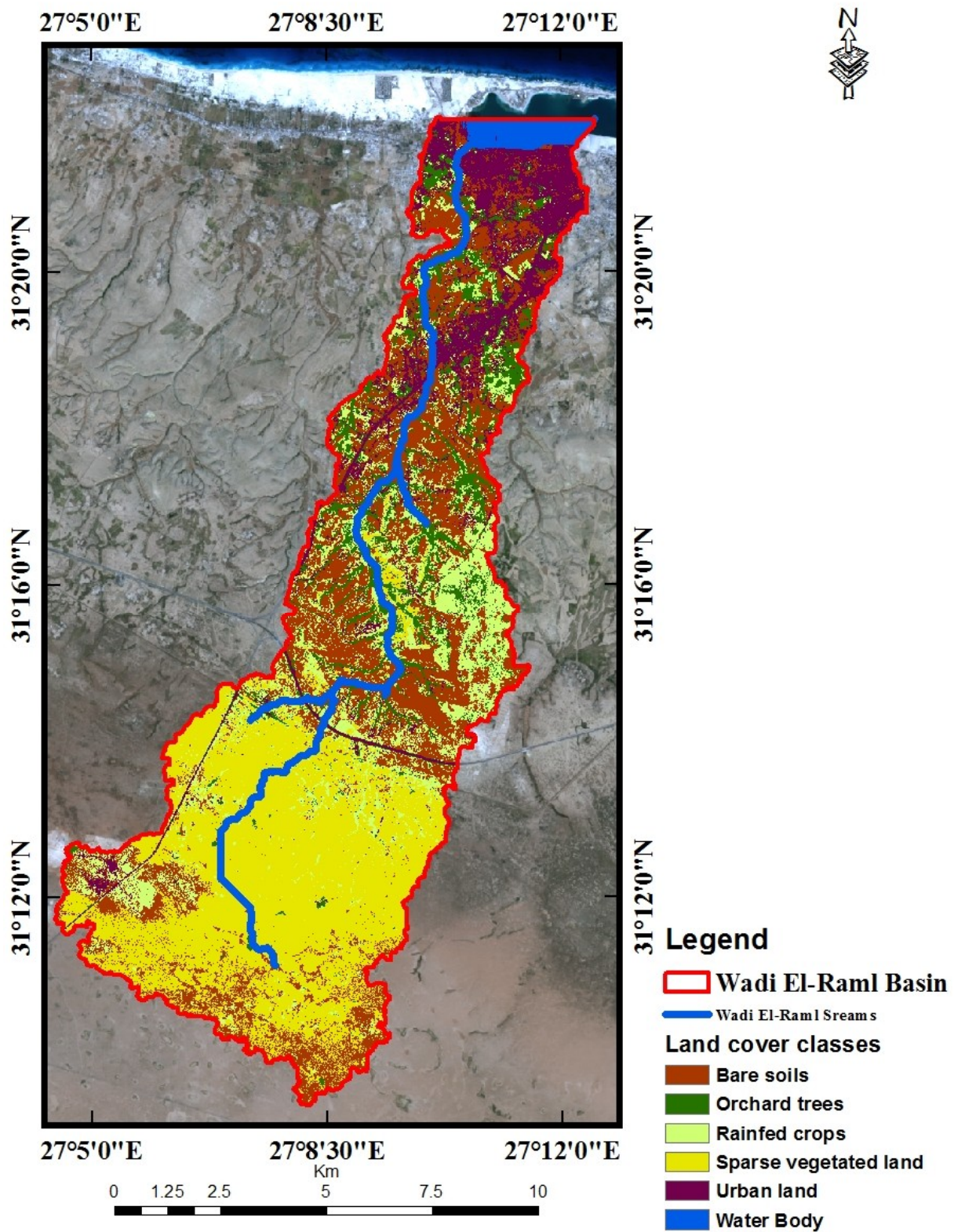

Figure 6. Land cover map of Wadi El-Raml based on supervised classification algorithm 
K2 first calculates the infiltration capacity when rainfall rate < infiltration rate using the Smith-Parlange model (Smith and Parlange, 1978) as follows:

$$
f_{c}(t)=K_{S}\left\{1+\frac{\alpha}{e^{\alpha F(t) /\left[(G+h)\left(\Phi-\theta_{i}\right]\right.}}\right\}
$$

Whereas , $f_{c}(t)$ is the infiltration capacity $\left(\mathrm{LT}^{-}\right.$ $\left.{ }^{1}\right), K_{s}$ is the soil hydraulic conductivity $\left(\mathrm{LT}^{-1}\right), \alpha$ is the soil parameter, 0 for sand and 1 for well mixed loam, $F(t)$ is the calculated depth of infiltrated water (L), $G$ is the net capillary drive (L), $h$ is the flow depth $(\mathrm{L}), \Phi$ is the soil porosity $\left(\mathrm{L}^{3} \mathrm{~L}^{-3}\right), \theta_{i}$ is the initial soil water content

When the rainfall rate exceeds the infiltration capacity, the model uses the kinematic wave equation to calculate the over land flow as follows:

$$
\frac{\partial h}{\partial t}+\alpha m h^{m-1} \frac{\partial h}{\partial x}=q(x, t)(2)
$$

Where, $t$ is the time (T), $x$ is the distance along the slope direction (L), $q$ is the lateral flow rate $\left(\mathrm{LT}^{-1}\right), \alpha$ and $m$ are parameters related to slope, surface roughness and flow regime

After the water reaches the channel, the model uses a similar approach to calculate the channel flow as follows:

$$
\frac{\partial A}{\partial t}+\frac{\partial Q}{\partial x}=q_{c}(x, t)(3)
$$

Where, $A$ is the cross sectional area $\left(\mathrm{L}^{2}\right), Q$ is the channel discharge $\left(\mathrm{L}^{3} \mathrm{~T}^{-1}\right), q_{c}(x, t)$ is the net lateral inflow per unit length of channel $\left(\mathrm{LT}^{-1}\right)$

Table 1.Parameters and their values used in the model calibration (modified from Abdalla 2016)

\begin{tabular}{lcc}
\hline Parameter & Planes & Channels \\
\hline Saturated hydraulic conductivity (Ks; mm /h) & 1.54 & 100 \\
Mean Capillary drive (G;mm) & 100 & 260 \\
Maximum soil saturation (0-1) Smax & 0.7 & - \\
Pore size distribution index $\lambda$ (DIST) & 0.32 & 0.38 \\
Soil porosity $\theta$ & 0.1 & 0.44 \\
Manning's coefficient (n) & 0.035 & 0.035 \\
Volumetric rock fraction (Rock) & 0.85 & 0 \\
\hline
\end{tabular}

Besides calculating the infiltration capacity and surface runoff, the model also calculates the sediment transport which is given by mass-balance equation similar to that for kinematic water flow (Bennett, 1974). Splash erosion was determined using the method described in Meyer and Wischmeier (1969). Hydraulic Erosion is modeled as kinetic transfer process and sediment transport capacity is modeled as proposed by Engelund and Hansen (1967).The estimation of these outputs involves parameters that can be adjusted to match the model prediction with the observed reality. Table (1) shows the calibrated parameters and their values as proposed by Abdalla (2016) that were used to calibrate KINEROS2 model for the simulation of the water balance components in Wadi El Kharouba (Fig.1)

\subsection{Simulated scenarios}

Three scenarios were simulated using the KINEROS2 model i.e., 1) baseline simulation of the current condition, 2) converting sparsely vegetated rangelands to rainfed crops and 3 ) converting bare soil to sparsely vegetated rangelands. The model was run for the three scenarios using the rainfall data of five major events in 2015/2016 rainy season. These events were as follows; 1) 26 October 2015 (27.20 mm received in 10 hours), 2) 04 November 2015 (10 $\mathrm{mm}$ received in 0.5 hours), 4) 13 December 2015 (18 mm received in 14 hours ), and 5) 30 December 2015 ( $24.80 \mathrm{~mm}$ received in 14 hours).

\subsection{Model calibration}

Distributed Hydrological models such as KINEROS2 are powerful tools for simulating the water balance components and sediment yield under land cover change conditions. However, to obtain realistic modeling results, an accurate calibration should be performed. One problem of calibrating the hydrological models is the availability and accuracy of the measured data. In this study, we transferred the calibrated parameters from a neighboring gauged watershed i.e., hour ), 3) 16 November 2015 (20 mm received in 5 
El Kharouba (Fig.1) of a study done by (Abdalla, 2016) to our ungauged watershed i.e. El Raml. Many studies have proved the effectiveness of transferring the calibrated parameters from gauged to ungauged watershed in simulating the flow dynamics (Kokkonen et al., 2003 , Bardossy et al., 2007 and Gao et al., 2015).

\section{RESULTS AND DISCUSSION}

Wadi El-Raml has faced significant land use changes in the last 15 - 20 years where several farmers started to use ground water to establish and irrigate small fields of vegetable crops as well as converting the rangelands into areas of rainfed crop cultivation including barley and wheat. These new land use types resulted in an increase of the tillage activity in the area. Total vegetation cover decreased to $28 \%$ in spring of 2015, which indicates vegetation degradation in Wadi El Raml. Overgrazing and land use change by increasing cultivation activities in this habitat based on ground water have removed the vegetation cover that protects soil from erosion. Connolly et al., (1997) reported that when the percent of vegetation cover is less than $30-40 \%$, runoff and soil loss dramatically increase.

\section{Rangeland vegetation ground survey}

Rangeland vegetation survey indicated that Wadi El Raml is rich in range plants, where 23 range plants were recorded, most of them are palatable (Table, 2). These include Deverra tortousa, Artemisia herba-alba, Gymnocarpos decander, Lycium shawii, Noaea mucronata, Suaeda pruinosa, Lotus polyphyllus, Haloxylon scoparium, Atractylis carduus and Zygophyllum album. Results in Table (2) show that total vegetation cover in spring of 2015 was $28.55 \%$. The highest plant cover of $3.3 \%$ was recorded by Lycium shawii in spring, 2015. Thymelaea hirsute attained the highest value of plant height $(92.6 \mathrm{~cm})$ while Fagonia arabica showed the lowest value of plant height (5.2 $\mathrm{cm})$. Vegetation survey from spring of 2015 showed that the fresh weight and productivity of Thymelaea hirsute were the highest in this habitat; however, this is an unpalatable plant and is mainly used as firewood in the area.

Table 2.Vegetation Analysis and Rangeland Productivity of Wadi El-Raml at spring of 2015

\begin{tabular}{|c|c|c|c|c|c|c|c|}
\hline Species Name & Density & $\begin{array}{c}\text { Cover } \\
\%\end{array}$ & Frequency & $\begin{array}{c}\text { Importance } \\
\text { value }\end{array}$ & $\begin{array}{c}\text { Plant } \\
\text { height } \\
(\mathrm{cm})\end{array}$ & $\begin{array}{c}\text { Fresh } \\
\text { weight } \\
\text { (kg/ha) }\end{array}$ & $\begin{array}{c}\text { Productivity } \\
\text { (kg dry } \\
\text { matter/ha) }\end{array}$ \\
\hline Artemisia herba-alba Asso & 5.9 & 1.35 & 100 & 19.2 & 46.0 & 2.1 & 1.6 \\
\hline Thymelaea hirsute (L.) Endl & 4.7 & 1.79 & 100 & 11.9 & 92.6 & 21.2 & 12.3 \\
\hline Oryzopsis miliacea (L.) Asch. \& & 32.2 & 1.15 & 100 & 37.1 & 68.1 & 11.3 & 7.5 \\
\hline Lygeum spartum Loefl & 19.1 & 1.82 & 100 & 41.6 & 57.1 & 1.6 & 0.8 \\
\hline Noaea mucronata (Forssk.) Asch. & 6.8 & 2.3 & 33.3 & 3.8 & 12.3 & 2.7 & 1.8 \\
\hline Asparagus stipularis - Forssk & 3.2 & 1.2 & 33.3 & 3.2 & 16.8 & 1.2 & 0.8 \\
\hline Atractylis carduus (Forssk.) & 0.8 & 0.3 & 33.3 & 3.2 & 63.3 & 11.5 & 6.3 \\
\hline Gymnocarpos decander Forssk. & 10.3 & 1.7 & 100 & 19.6 & 19.5 & 13.2 & 6.8 \\
\hline Deverra tortousa (Desf.) DC. & 36 & 1.28 & 100 & 46.4 & 33.1 & 13.7 & 7.9 \\
\hline Reaumuria hirtella Jaub. \& Spach & 0.1 & 0 & 33.3 & 3.1 & 18.3 & 0.6 & 0.4 \\
\hline Thymus capitatus (L.) Hoffsgg. \& & 2.7 & 0.75 & 100 & 12.5 & 20.9 & 0.26 & 0.21 \\
\hline Suaeda pruinosa Lange & 2.3 & 2.3 & 33.3 & 10.1 & 29.3 & 0.8 & 0.3 \\
\hline Centaurea eryngioides Lam. & 5.3 & 0.24 & 33.3 & 7.0 & 36.0 & 3.4 & 1.7 \\
\hline Lotus polyphyllus E. D. Clarke & 9.3 & 0.7 & 66.7 & 28.8 & 7.7 & 6.7 & 2.8 \\
\hline Ononis vaginalis M.Vahl & 1.0 & 0.5 & 33.3 & 17.1 & 25.7 & 12.8 & 7.3 \\
\hline Zygophyllum album ( L.) & 9.2 & 3.1 & 33.3 & 14.6 & 29.5 & 14.8 & 3.9 \\
\hline Helianthemum lippii (L.) & 80.3 & 1.27 & 100 & 47.4 & 9.3 & 3.7 & 2.9 \\
\hline Haloxylon scoparium Pomel & 6.7 & 1.35 & 100 & 30.8 & 16.0 & 10.9 & 8.1 \\
\hline Lycium shawii Roem. \& Schult & 3.3 & 3.3 & 100 & 13.4 & 28.0 & 15.3 & 8.2 \\
\hline Allium desertarum (L.) & 0.7 & 0.2 & 33.3 & 3.8 & 31.0 & 2.4 & 1.3 \\
\hline Echium sericeum Vahl. & 0.3 & 0.45 & 0 & 1.0 & 13.6 & 0.5 & 0.2 \\
\hline Asphodelus ramosus (L.) & 10.3 & 1.1 & 66.7 & 13.8 & 5.6 & 8.9 & 5.3 \\
\hline Fagonia arabica Linn. & 0.5 & 0.4 & 33.3 & 0.4 & 5.2 & 8.3 & 4.7 \\
\hline
\end{tabular}




\section{Crop production in the wadi}

Results from the two field experiments for the two crops are presented in Table (3). It is quite clear that barley produced higher grain, straw and biological yields as compared to wheat. Barley is well known as a drought tolerant crop as compared to wheat with better water use efficiency and mechanisms of drought escape. Hence, under these dry conditions barley tends to produce higher number of tillers, number of spikes/unit area but shorter plants as compared to wheat. In the current study the crop yield was low which recorded $0.765 t /$ ha for wheat and $1.13 \mathrm{t} / \mathrm{ha}$ for barley for the 2015/2016 winter season (Table 3).

\section{KINEROS2 model simulation}

\subsection{Baseline simulation}

A baseline simulation was run to describe the current condition, and it resulted in a runoff volume of 174321, 32744 ,116497, 6454 and $19422 \mathrm{~m}^{3}$ and total sediment yield from the upland area of 1.49, 0.36, 0.90, 0.027 and $0.112 \mathrm{t} / \mathrm{ha}$, for the $1 \mathrm{st}, 2 \mathrm{nd}, 3 \mathrm{rd}, 4$ th and 5 th rainfall events respectively. From the baseline simulation, it is quite clear that lower sediment yield at the outlet, as compared to the upstream, was observed, and this is due to the nature of the model that some sediments are deposited in the upland and don't reach the outlet.

\subsection{Impact of converting the range lands to rainfed crops}

After delineating the watershed boundaries, the model divides the watershed to a number of smaller units called sub-watersheds or sub-basins. Table (4) lists the sub-basins of Wadi El-Raml associated with their land cover types and the dominant land cover in each sub-basin. The impact of the tested scenario on infiltration, surface runoff, sediment yield and peak flow is shown in Table (5) as percentage increases in surface runoff and sediment yield,

The impact was notable among the sub-basins, and the differences are governed by the relative area under the tested scenario. The highest impact was noted for the sub-basins No 42 and 52 (Figures 7 and 8) in the surface runoff and sediment yield where most of the S1 Scenario is taking place. These two sub-basins showed an increase in the surface runoff by almost $40 \%$ and sediment yield by more than $90 \%$ when compared by the baseline scenario. However sub-basins No 12 and 13 witnessed comparatively no impact, where the increase in surface runoff and sediment yield was zero (Figures 7 and 8).

Converting the rangelands to croplands increased the erosion and surface runoff. Similar results of increasing the surface runoff by converting the rangelands to rainfed agriculture were obtained by Ghaffari et al., (2010), who found that converting only $12 \%$ of the grassland into rainfed agriculture increased the total annual surface runoff of the watershed by $43 \%$.

This increase in the surface runoff and sediment yield may likely have a severe negative impact on the ecosystems (Yasouri et al., 2012), where, land use conversion from rangeland to dry farming, between the year 1970 and 2007, increased the annual sediment yield of the Kardeh basin in Iran to two fold. Thus adoption of $\mathrm{S} 1$ requires additional recommendations to avoid excessive erosion and surface runoff, which could be done by using different land management practices e.g. mulching, water harvesting ,terracing, contour furrow, conservation tillage....etc. These management applications may help in increasing the crop yield as well as conserving the soil and water resources. Also, it is important to increase the farmers' awareness related to the connection between soil erosion and their activities.

\subsection{Impact of converting the bare soil to rangeland}

Under the second scenario (Table 5) a reduction in the surface runoff, sediment yield and peak flow was recorded from all the simulated events. The sub-basins responded differently to the land cover change i.e., the highest affected sub-basins were 23, 12, 13, 31 and 32 for all the tested events. On the contrary, sub-basin number 42 was not affected by the land cover change (Figures 7 and 8).

The hydrograph results in Figure 9 showed that the peak flow was increased when the land cover was changed from rangelands to rainfed crops. However it was decreased associated with a delay for the timing of the peak flow when the land cover was changed from bare soil to rangelands.

The results showed that converting the bare soil to rangelands decreased the surface runoff and sediment yield. The reduction of the surface runoff and sediment yield is due to the fact that vegetation and ground cover can protect the surface from raindrop splash erosion and slowdown overland flow. Moreover, vegetation patches can capture runoff nutrient and sediment (Urgeghe et al., 2010) and also reduce and slightly delay the peak flow. Changes in land cover can have a drastic effect on the storage and movement of water on the landscape. Erosion is a result of the lack of adequate vegetation cover to retain soil and water in the upstream. A strong correlation between the biomass on hillslope and the overland flow was recorded (Turnbull et al., 2008). 
Table 3. Crop yield and its parameters for wheat and barley grown in wadi El-Raml during the 2015/2016 growing season

\begin{tabular}{ccccccccc}
\hline Crop & $\begin{array}{c}\text { PH } \\
(\mathbf{c m})\end{array}$ & NGS & $\begin{array}{c}\text { 1000GW } \\
(\mathbf{g})\end{array}$ & $\begin{array}{c}\text { GY } \\
\left(\mathbf{g} / \mathbf{m}^{\mathbf{2}}\right)\end{array}$ & $\begin{array}{c}\text { SY } \\
\left(\mathbf{g} / \mathbf{m}^{\mathbf{2}}\right)\end{array}$ & $\begin{array}{c}\text { BY } \\
\left(\mathbf{g} / \mathbf{m}^{\mathbf{2}}\right)\end{array}$ & $\begin{array}{c}\text { HI } \\
(\boldsymbol{\%})\end{array}$ & $\begin{array}{c}\text { CI } \\
(\boldsymbol{\%})\end{array}$ \\
\hline Wheat & 57.33 & 34.00 & 35.42 & 76.50 & 171.40 & 247.90 & 30.85 & 44.63 \\
Barley & 37.57 & 48.00 & 32.35 & 113.07 & 185.27 & 298.34 & 37.89 & 61.03 \\
\hline
\end{tabular}

Where;PH plant height,NGS number of grains/spike, 1000GW 1000 grain weight, GY grain yield, SY straw yield, BY biological yield, HI harvest index and CI crop index

Table 4. Number of cells and percentages of land cover types of the entire basin and its sub-basins

\begin{tabular}{|c|c|c|c|c|c|c|c|c|c|c|c|c|c|}
\hline \multirow{4}{*}{$\begin{array}{l}\text { Main Basin } \\
\text { and } \\
\text { sub-basins }\end{array}$} & \multicolumn{13}{|c|}{ Land Cover Type } \\
\hline & \multicolumn{2}{|c|}{ Water Body } & \multicolumn{2}{|c|}{ Urban land } & \multicolumn{2}{|c|}{ Orchards trees } & \multicolumn{2}{|c|}{ Rainfed crops } & \multirow{2}{*}{\multicolumn{2}{|c|}{$\begin{array}{c}\text { Sparse } \\
\text { vegetated land } \\
\end{array}$}} & \multicolumn{2}{|c|}{ Bare soils } & \multirow[t]{3}{*}{ Total } \\
\hline & & & & & & & & & & & & & \\
\hline & Cells & $\%$ & Cells & $\%$ & Cells & $\%$ & Cells & $\%$ & Cells & $\%$ & Cells & $\%$ & \\
\hline El Raml Basin & 17244 & 1.51 & 130637 & 11.43 & 119138 & 10.42 & 180670 & 15.80 & 397923 & 34.81 & 297643 & 26.03 & 1143255 \\
\hline Sub-basin 12 & 2041 & 0.96 & 79765 & 37.69 & 40248 & 19.02 & 23115 & 10.92 & 242 & 0.11 & 66250 & 31.30 & 211661 \\
\hline Sub-basin 13 & 14312 & 13.96 & 24851 & 24.25 & 18837 & 18.38 & 13847 & 13.51 & 198 & 0.19 & 30442 & 29.70 & 102487 \\
\hline Sub-basin 22 & 0 & 0.00 & 6852 & 2.72 & 20874 & 8.28 & 39599 & 15.71 & 139032 & 55.15 & 45747 & 18.15 & 252104 \\
\hline Sub-basin 23 & 0 & 0.00 & 6852 & 2.72 & 20874 & 8.28 & 39599 & 15.71 & 139032 & 55.15 & 45747 & 18.15 & 252104 \\
\hline Sub-basin 31 & 0 & 0.00 & 3435 & 3.74 & 15148 & 16.51 & 42753 & 46.61 & 1285 & 1.40 & 29111 & 31.73 & 91732 \\
\hline Sub-basin 32 & 0 & 0.00 & 309 & 11.63 & 606 & 22.81 & 519 & 19.53 & 10 & 0.38 & 1213 & 45.65 & 2657 \\
\hline Sub-basin 33 & 0 & 0.00 & 1 & 0.27 & 226 & 59.95 & 25 & 6.63 & 1 & 0.27 & 124 & 32.89 & 377 \\
\hline Sub-basin 41 & 0 & 0.00 & 223 & 0.10 & 1453 & 0.67 & 8273 & 3.80 & 154833 & 71.04 & 53170 & 24.40 & 217952 \\
\hline Sub-basin 42 & 0 & 0.00 & 241 & 1.41 & 365 & 2.13 & 1657 & 9.66 & 14270 & 83.23 & 612 & 3.57 & 17145 \\
\hline Sub-basin 43 & 0 & 0.00 & 210 & 1.60 & 245 & 1.87 & 1414 & 10.80 & 10029 & 76.59 & 1196 & 9.13 & 13094 \\
\hline Sub-basin51 & 0 & 0.00 & 5806 & 7.23 & 1765 & 2.20 & 18373 & 22.89 & 37062 & 46.17 & 17263 & 21.51 & 80269 \\
\hline Sub-basin52 & 0 & 0.00 & 435 & 2.13 & 863 & 4.22 & 2318 & 11.33 & 15064 & 73.66 & 1770 & 8.66 & 20450 \\
\hline Sub-basin53 & 0 & 0.00 & 139 & 6.33 & 202 & 9.20 & 626 & 28.51 & 444 & 20.22 & 785 & 35.75 & 2196 \\
\hline
\end{tabular}

Table 5. Average percent change for various hydrological components under different proposed land use scenarios

\begin{tabular}{cccccc}
\hline Scenarios & Rainfall events & Infiltration $(\mathbf{m m})$ & $\begin{array}{c}\text { Surface } \\
\text { runoff }(\mathbf{m m})\end{array}$ & $\begin{array}{c}\text { Sediment } \\
(\mathbf{k g} / \mathbf{h a})\end{array}$ & $\begin{array}{c}\text { Peak flow } \\
\left(\mathbf{m}^{\mathbf{3}} / \mathbf{s}\right)\end{array}$ \\
\hline & 26Oct.2015 & -1.98 & 15.37 & 36.45 & 18.11 \\
& 04Nov.2015 & -2.58 & 9.47 & 29.53 & 12.52 \\
S1 & 16Nov.2015 & -1.76 & 10.12 & 25.67 & 14.61 \\
& 13Dec.2015 & -1.15 & 15.34 & 27.80 & 16.00 \\
& 30Dec.2015 & -0.811 & 6.39 & 16.29 & 10.65 \\
& 26Oct.2015 & -0.72 & -10.76 & -19.18 & -11.21 \\
& 04Nov.2015 & -1.83 & -20.31 & -28.74 & -18.48 \\
S2 & 16Nov.2015 & -0.66 & -14.37 & -22.77 & -12.99 \\
& 13Dec.2015 & -2.02 & -12.77 & -20.46 & -11.89 \\
& 30Dec.2015 & -1.00 & -22.65 & -31.48 & -18.85 \\
\hline
\end{tabular}

\section{CONCLUSION}

The rapid degradation of natural vegetation caused by human and climate induced factors highly influenced the hydrology of the watershed. In general, converting the rangeland to agriculture increased both the surface runoff and sediment yield. However, converting the bare soil to range land decreased the two components of surface runoff and sediment yield. An integrated high resolution satellite image with hydrological models is very helpful to detect the environmental changes and their impact on the hydrology of the watershed. This is also very helpful to evaluate better options for sustainable development of land and water resources. 


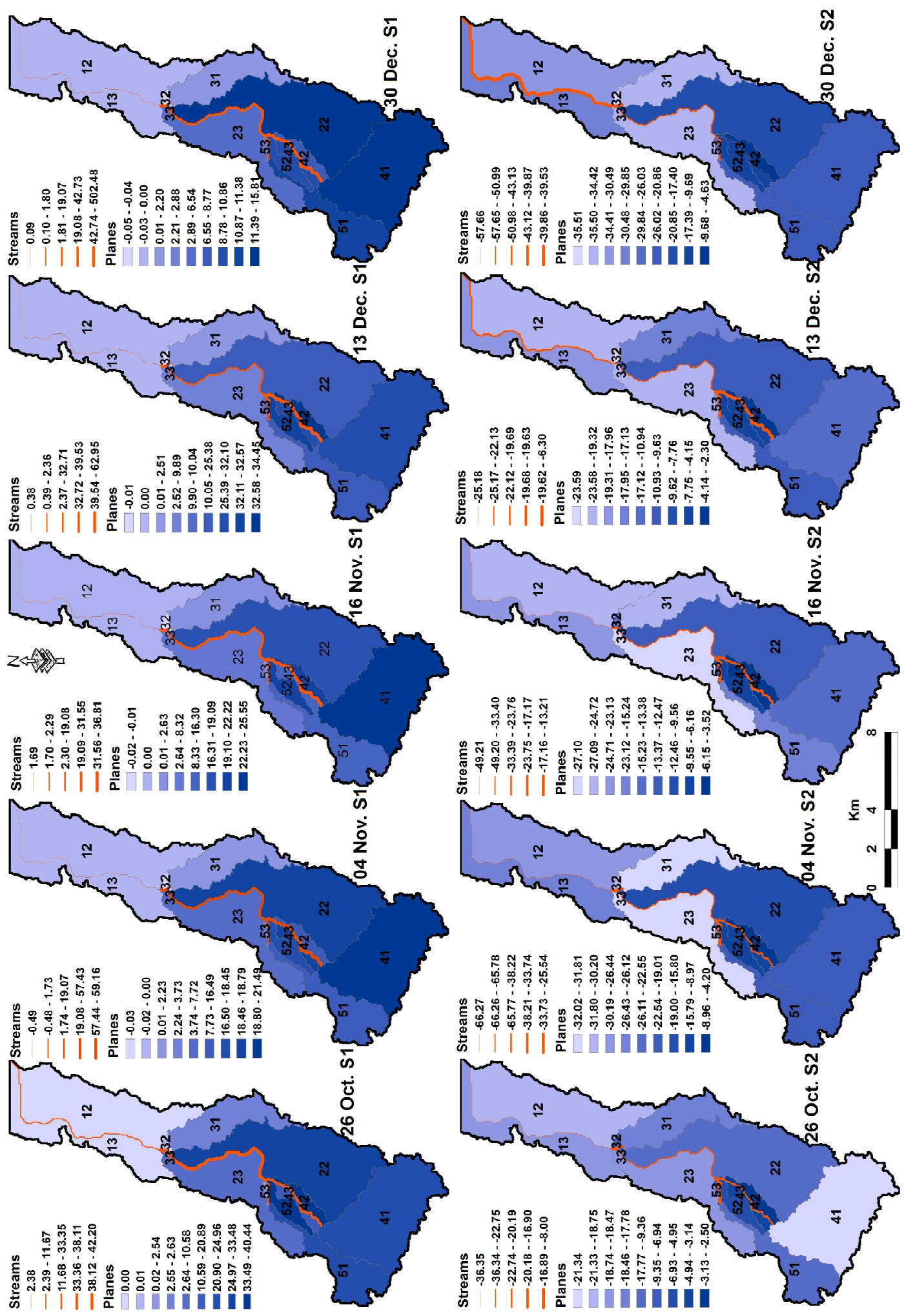

Figure 7. Percent change of surface runoff ( $\mathrm{mm}$ ) under the first scenario (up) and the second scenario (down) for the five studied rainfall events 

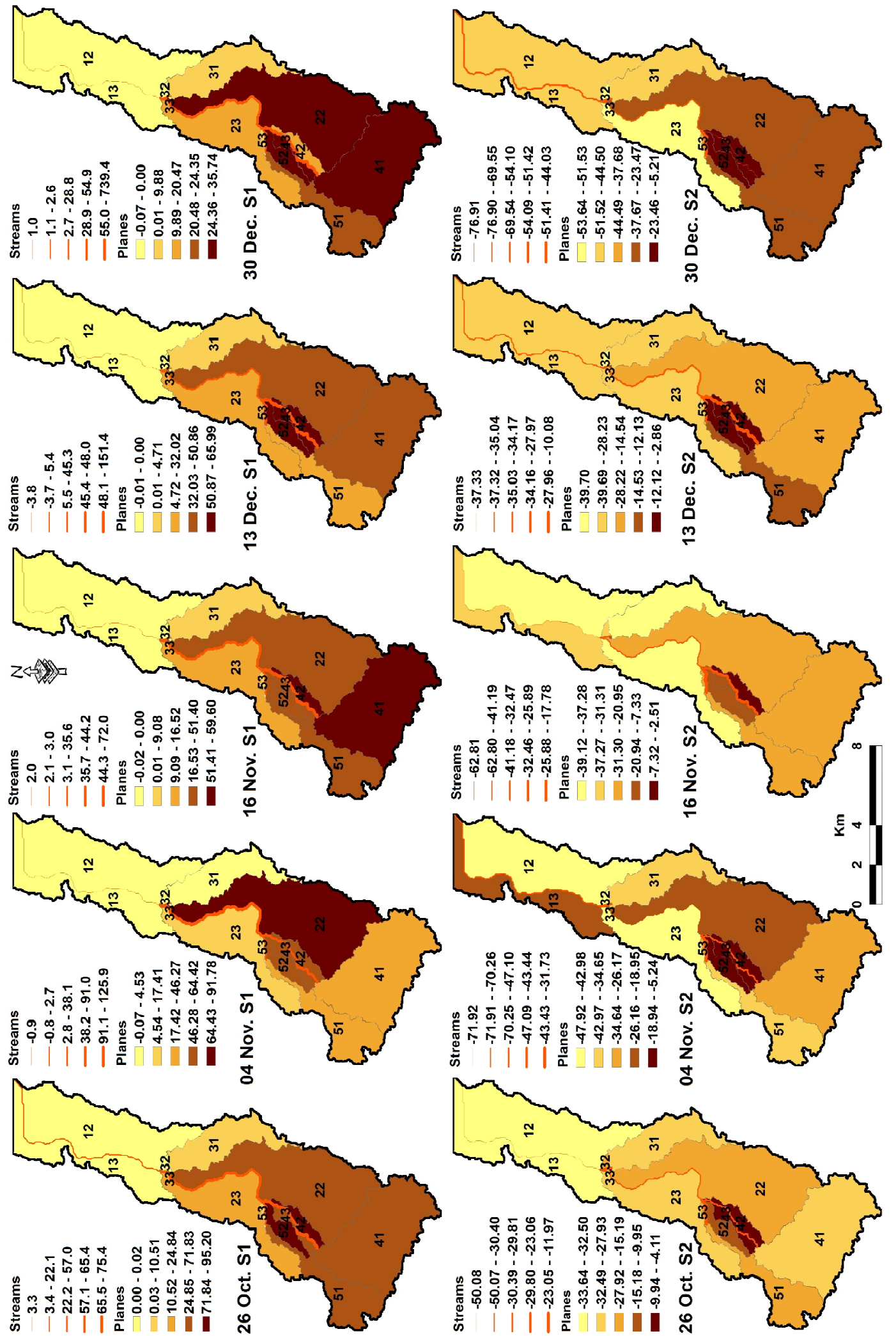

Figure 8. Percent change of sediment yield (kg/ha) under the first scenario (up) and the second scenario (down) for the five studied rainfall events 


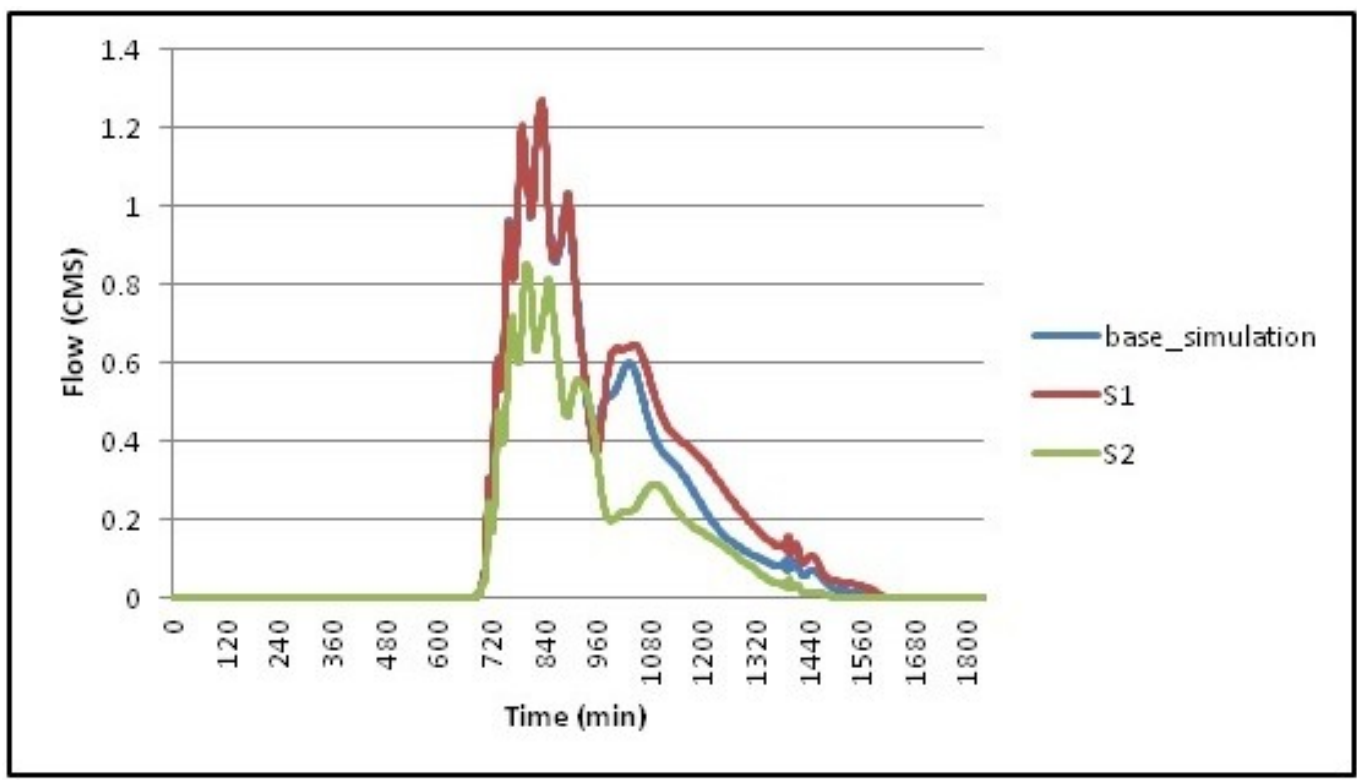

Figure 9. Runoff hydrograph from a single rainfall event (270ct.2015) under different scenarios

\section{REFERENCES}

Abdalla, M.A.I. 2016. A rainfall-runoff model for water management in Wadi systems based on hydropedological studies (master's thesis), International Centre for advanced Mediterranean agronomic studies, Mediterranean Agronomic Institute of Bari (CIHEAM-IAMP)

Arnold, J.G., R. Srinivasan, R. S. Muttiah, J.R. Williams. 1998. Large area hydrologic modeling and assessment part I: model development. J. Am. Water Resour. Assoc. 34: 73-89.

Bardossy, A. 2007.Calibration of hydrological model parameters for ungauged catchments. Hydrol. Earth Syst. Sci. 11(2):703-710

Barseem, M. S., A. N. El Sayed and A. M. Youssef. 2014. Impact of geologic setting on the groundwater occurrence in wadis El Sanab, Hashem, and Khrega using geoelectrical methods-northwestern coast, Egypt. Arab J. Geosci. 7(12):5127-5139.

Bennett, J.P. 1974, Concepts of mathematical modeling of sediment yield. Water Resour. Res. 10(3): 485-492.

Beven, K.J. and M. J. Kirkby. 1979. A physically based, variable contributing area model of basin hydrology. Bulletin des Sciences Hydrologiques. 4(1): 43-69.

Boulos, L. 1995: Check list Flora of Egypt. Vol. one. A1Hadara Publishing, Cairo, Egypt.

Connolly, R.D., C.A. Ciesiolka, D.M. Silburn and C. Carroll.1997. Distributed parameter hydrology model (Answers) applied to a range of catchment scales using rainfall simulator data. IV Evaluating pasture catchment hydrology. J. Hydro. 201: 311-328.

Dwarakish, G. S. and B.P. Ganasri .2015. Impact of land use change on hydrological systems; A review of current modeling approaches. Cogent Geoscience.1:1-18.
Engelund, F. and E. Hansen . 1967. A Monograph on Sediment Transport in Alluvial Streams, Teknisk Forlag, Copenhagen.62 pp

Fang, N.,Z. Shi ,L. Li ,Z. Guo ,Z. Liu and L. Ai .2012. The effects of rainfall regimes and land use changes on runoff and soil loss in a small mountainous watershed. Catena.99:1-8.

FAO/UNESCO. 2003. Digital Soil Map of the World and Derived Soil Properties, CD-ROM, Version 3.6. Information Division, FAO, Viale delle Terme di Caracalla, 00100 Rome, Italy.

Gao, W., H. C. Guo and Y. Liu. 2015. Impact of Calibration Objective on Hydrological Model Performance in Ungauged Watersheds. J. Hydrol. Eng. 20:8, 04014086.

Ghaffari G.,S. Keesstra ,J. Ghodousi and H. Ahmadi.2010. SWAT-simulated hydrological impact of land-use change in the Zanjanrood Basin, Northwest Iran. Hydrol. Process.24: 892 - 903

Gumindoga, W. ,T.H.M. Rientjes ,A.T. Haile and T. Dube .2014. Predicting streamflow for land cover changes in the Upper Gilgel Abay River Basin, Ethiopia: A TOPMODEL based approach. Phys. Chem. Earth.76-78,3-15

Im, S.,H. Kim , C. Kim and C. Jang . 2009. Assessing the impacts of land use changes on watershed hydrology using MIKE SHE. Environ. Geol. 57:231-239.

Khalifa, M.E.A. and N.F. Beshay .2015. Soil Classification and Potentiality Assessment for Some Rainfed Areas at West of Matrouh, Northwestern Coast of Egypt. Alexandria Sci. Exchange J. 36 (4): 325-341

Kokkonen, T. S., A. J. Jakeman, P.C. and H. J. Koivusalo. 2003. Predicting daily flows in ungauged catchments: Model regionalizationfrom catchment descriptors at the Coweeta hydrologic laboratory, North Carolina. Hydrol. Processes. 17(11): 2219-2238 
Li, Y.J. Chang, Y. Wang ,W. Jin and A. Guo .2016. Spatiotemporal Impacts of Climate, Land Cover change and direct human activities on runoff variations in the Wei river basin, China. Water.(8)220:1-21.

Ludwig, J. A. and J. F. Reynolds. 1988: Statistical Ecology: a primer on methods and computing. New York, USA.

Mahmoud, S. H. and A. A. Alazba .2015. Hydrological Response to Land Cover Changes and Human Activities in Arid Regions Using a Geographic Information System and Remote Sensing. PLOS ONE, DOI:10.1371/journal.pone.0125805,1-8.

Masih, I.,S. Maskey ,S. Uhlenbrook and V. Smakhtin. 2011. Impact of upstream changes in rain-fed agriculture on downstream flow in a semi-arid basin. Agr. Water Manage. 100 (1):36-45.

Masoud, M. H. Z. 2000. Assessment of surface runoff in Marsa Matrouh area, Northwestern Coastal Zone, Egypt. M.Sc. Thesis, Faculty of Science, Alexandria University, Egypt, 166 p.

Meyer, L.D., and W. H. Wischmeier .1969. Mathematical simulation of the process of soil erosion by water. T. Am. Soc. Agr. Eng. 12(6): 754-762.

Miller, S. N., D. J. Semmens, D. C. Goodrich, M. Hernandez, R. C. Miller, W. G. Kepner, and D. P. Guertin. 2007. The automated geospatial watershed assessment tool. J. Environ. Mod. Softw. 22(3): 365-377.

Mueller-Dombois, D. and H. Ellenberg. 1974: Aims and methods of vegetation ecology. Pub. John Wiley \& Sons, Inc. New York, U.S.A.

Pervez M S and G. M. Henebry .2015. Assessing the impacts of climate and land use and land cover change on the fresh water availability in the Brahmaputra river basin. J. Hydrol.; Regional Studies.3:285-311.

Raslan, S.M. 1995. Geomorphological and hydrological studies on some localities along the Northwestern Coast of Egypt. M.Sc. Thesis, Faculty of Science, Menoufia University.

Refsgaard, J.C. and B. Storm. 1995. MIKE SHE. In Computer Models of Watershed Hydrology; Singh, V.P.,Ed.; Water Resources Publications: Highlands Ranch, CO, USA. pp. 809-846.

Schmidt, H. and A. Karnieli. 2000. Remote sensing of the seasonal variability of vegetation in a semi-arid environment. J. Arid Environ. 45: 43-59
Semmens, D. J., D. C. Goodrich, C. L. Unkrich, R. E. Smith, D. A. Woolhiser, and S. N. Miller. 2008. Chapter 5: KINEROS2 and the AGWA modeling framework. In Hydrological Modelling in Arid and Semi-Arid Areas, 4969. H. Wheater, S. Sorooshian, and K. D. Sharma, eds. Cambridge, U.K.: Cambridge University Press.

Sen, Z., (2008): Wadi hydrology. CRC Press, Taylor \& Francis Group.

Smith, R.E. and J. Y. Parlange. 1978. A parameter-efficient hydrologic infiltration model, Water Resour. Res. 14(3):533-538.

Smith, R. E., D. C. Goodrich, D. A., Woolhiser, and C. L. Unkrich, 1995. KINEROS: A Kinematic Runoff and Erosion Model. In: Computer Models of Watershed Hydrology, V. P. Singh (Editor).Water Resources Publications, Highlands Ranch, Colorado.pp.697-732.

Soil Survey Staff. 2014. Keys to Soil Taxonomy, 12th ed. USDA-Natural Resources Conservation Service, Washington, DC.

Tackholm, Vivi, 1974. Students Flora of Egypt 2th Ed. Published by Cairo Univ. 888pp.

Turnbull, L., J. Wainwright and R. E. Brazier. 2008. A conceptual framework for understanding semi-arid land degradation: Ecohydrological interactions across multiple space and time scales. Ecohydrology.1:23-34.

Urgeghe, A. M., D. D. Breshears, S. N. Martens and P. C. Beeson. 2010. Redistribution of runoff among vegetation patch types: on ecohydrological optimality of herbaceous capture of run-on. Rangeland Eco. Manag. 63(5):497504.

Woolhiser, D. A., R. E. Smith, and D. C. Goodrich. 1990. KINEROS, A Kinematic Runoff and Erosion Model: Documentation and User Manual. ARS-77. Tucson, Ariz.: USDA-ARS _Southwest Watershed Research Center. Available at:Iwww.tucson.ars.ag.gov/kineros.

Yasouri, M.,N.A.B. Sulaiman and F. Saeidian . 2012. Conversion trends of rangelands to dry farming and its effects on erosion and sediment yield in Kardeh drainage basin. Caspian J. Env. Sci. 10 ,2 : 257-272. 


\section{الملخص العربي}

محاكاة تأثير التغير فى الغطاء النباتى على الأتزان المائى وكمية الترسيبات لوادى الرمل بالساحل

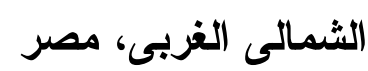

أشرف نور أحمد الصادق و أحمد حسين خريشى محمد مدئ

تم محاكاة تأثير تغيير الغطاء الأرضي بمنطقة أعالي وادي

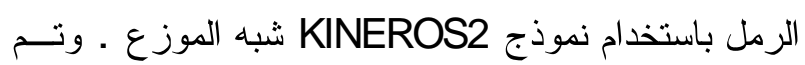

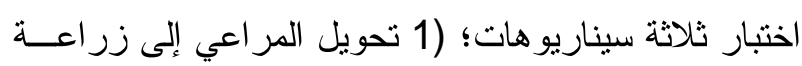

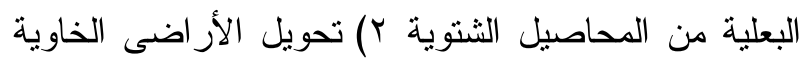

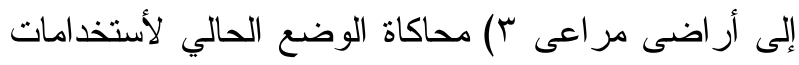

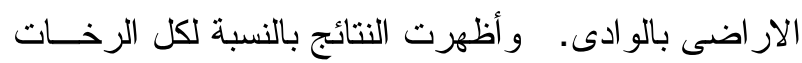

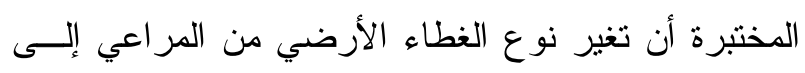
الزراعة البعلية أدى الى زيادة فى معدل النياء الارضى دن الجريان السطحي

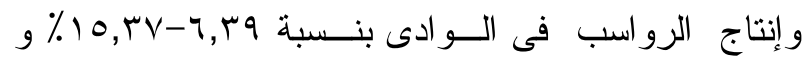

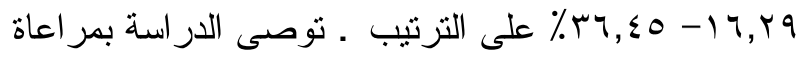
تحويل منطقة محدودة من المر اعي إلى الزر اعة البعلية.
تمثل الزراعة المطرية المصدر الرئيسى للغــــاء للبـــو

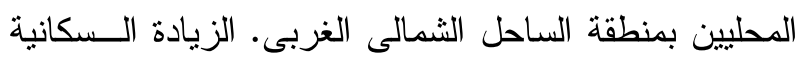

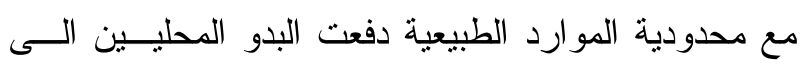

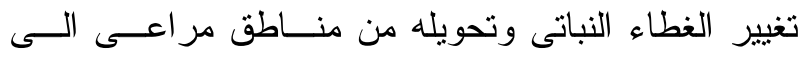
زراعات مطرية. فى هذه الدراسة، تم أستخدام بيانات صور

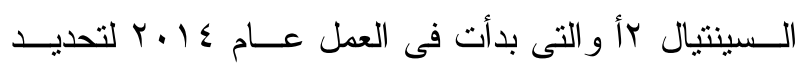

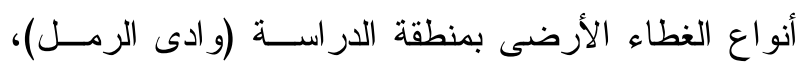

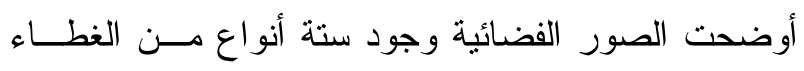

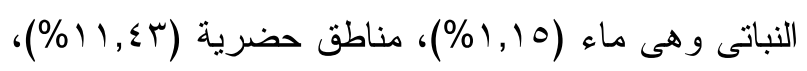

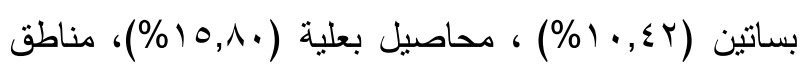

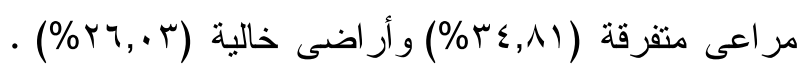

